\title{
Sudden collapse in a middle-aged male: giant ACOM aneurysm
}

\author{
Mueez Waqar, ${ }^{1}$ Anjum Habib Vohra ${ }^{2}$
}

${ }^{1}$ School of Medicine, University of Liverpool, Liverpool, UK ${ }^{2}$ Department of Neurosurgery, Lahore General Hospital, Lahore, Pakistan

\section{Correspondence to} Mueez Waqar, md0u92dd@liv.ac.uk
To cite: Waqar $\mathrm{M}_{\text {, }}$ Vohra AH. BMJ Case Rep Published online: [please include Day Month Year] doi:10.1136/bcr-2013201711

\section{DESCRIPTION}

A 50-year-old right-handed man with no medical history of note, presented to neurosurgery emergency with sudden loss of consciousness and vomiting. The patient was on the toilet when he was overcome by a sudden, severe headache, making him lose consciousness and collapse. He described the headache as akin to being hit in the back of the head with a cricket bat. The patient lay on the floor only briefly before relatives came to his aid; there was no witnessed tongue biting, incontinence or convulsions of note. His relatives noted him to be confused, reporting of a global headache and nausea, prompting them to take the patient to the hospital. On admission his Glasgow Coma Scale was $14 / 15$, losing one point for confusion, though there were no focal signs or pupillary abnormal-
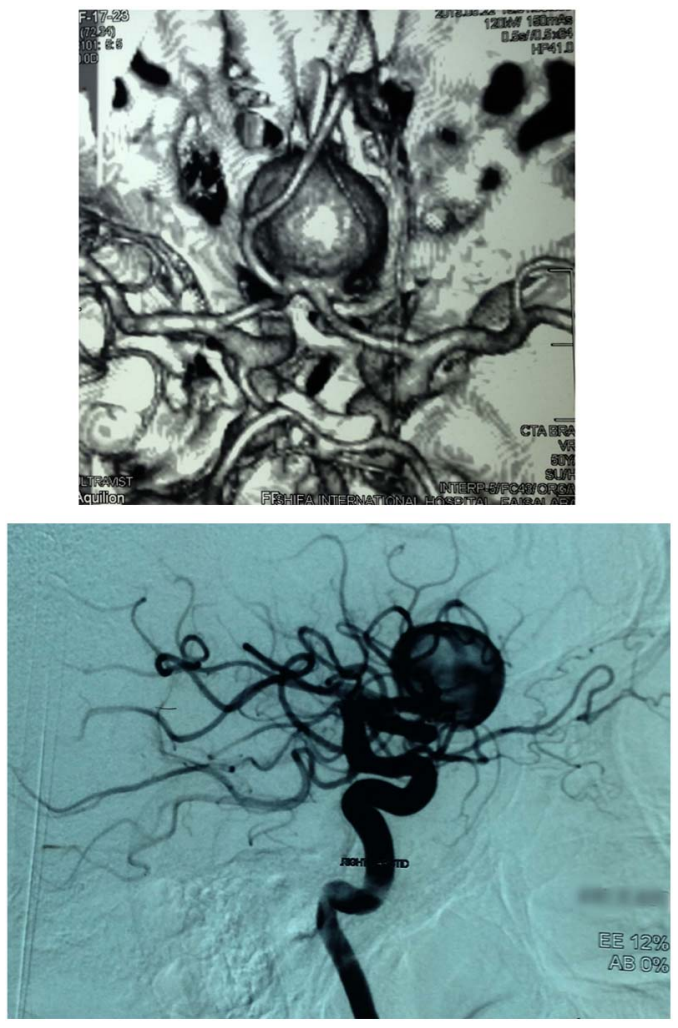

Figure 1 Giant anterior communicating artery aneurysm seen on CT angiography (top) and digital subtraction angiography (bottom). ities. CT of the head was performed which confirmed the presence of a subarachnoid hemorrhage. CT angiography and digital subtraction angiography revealed an anterior communicating (ACOM) artery aneurysm measuring $25 \mathrm{~mm}$ in diameter (see figure 1). The patient underwent craniotomy and clipping of the aneurysm, making a successful recovery thereafter.

Giant intracerebral aneurysms (GIA) are rare, often deadly, ticking time bombs measuring at least $25 \mathrm{~mm}$ in diameter. ${ }^{1}$ One longitudinal study showed the 5-year rupture rate of GIAs to be around $40-50 \%{ }^{2}$ highlighting the need for intervention as soon as possible after discovery. Treatment is a choice between surgical clipping and endovascular coiling, with many surgeons preferring surgical intervention given the low rate of occlusion after coiling procedures. ${ }^{3}$ Ultimately, the decision is based on numerous factors such as age, location and measures of cerebrovascular reserve. ${ }^{1}$

\section{Learning points}

- Giant intracerebral aneurysms should be treated soon after they are found.

- Management of giant intracerebral aneurysms is controversial, and the ultimate decision should be multidisciplinary, with multiple factors taken into account.

Contributors MW created the first draft of the article. AHV was responsible for the treatment of the patient, and he also checked over the draft.

Competing interests None.

Patient consent Obtained.

Provenance and peer review Not commissioned; externally peer reviewed.

\section{REFERENCES}

1 Gonzalez NR, Duckwiler G, Jahan R, et al. Challenges in the endovascular treatment of giant intracranial aneurysms. Neurosurgery 2006;59(5 Suppl 3):S113-24; discussion S3-13.

2 Nakase H, Shin Y, Kanemoto Y, et al. Long-term outcome of unruptured giant cerebral aneurysms. Neurol Med Chir (Tokyo) 2006;46:379-84; discussion 84-6.

3 Parkinson RJ, Eddleman CS, Batjer $\mathrm{HH}$, et al. Giant intracranial aneurysms: endovascular challenges. Neurosurgery 2008;62(6 Suppl 3):1336-45. 
Copyright 2013 BMJ Publishing Group. All rights reserved. For permission to reuse any of this content visit http://group.bmj.com/group/rights-licensing/permissions.

BMJ Case Report Fellows may re-use this article for personal use and teaching without any further permission.

Become a Fellow of BMJ Case Reports today and you can:

- Submit as many cases as you like

- Enjoy fast sympathetic peer review and rapid publication of accepted articles

- Access all the published articles

- Re-use any of the published material for personal use and teaching without further permission

For information on Institutional Fellowships contact consortiasales@bmjgroup.com

Visit casereports.bmj.com for more articles like this and to become a Fellow 